\title{
Penggunaan Putresin Alami dan Sintetik untuk Induksi Kalus dan Regenerasi Kultur Anter Empat Genotipe Padi
}

\author{
Nono Carsono ${ }^{1}$, Desy Lidiasari ${ }^{2}$, Santika Sari ${ }^{1}$, dan Noladhi Wicaksana ${ }^{1}$ \\ ${ }^{1}$ Laboratorium Pemuliaan Tanaman, Departemen Budidaya Pertanian, Fakultas \\ Pertanian, Universitas Padjadjaran, Kampus Jatinangor \\ Jln. Raya Bandung-Sumedang Km. 21 Jatinangor, Kab. Sumedang 45363 Jawa Barat \\ 2Prodi Agroteknologi, Fakultas Pertanian, Universitas Padjadjaran, Kampus Jatinangor \\ Jln. Raya Bandung-Sumedang Km. 21 Jatinangor, Kab. Sumedang 45363 Jawa Barat \\ Alamat Korespondensi: n.carsono@unpad.ac.id
}

\begin{tabular}{lrr}
\hline \multicolumn{2}{c}{ INFO ARTIKEL } & ABSTRACT/ABSTRAK \\
\hline Diterima: & $25-11-2021$ & \\
Direvisi: & $17-01-2022$ & The Use of Natural and Synthetic Putrescine for Callus Induction and \\
Dipublikasi: & $23-01-2022$ & Regeneration of Anther Culture of Four Rice Genotypes
\end{tabular}

Keywords:

Dihaploid, In vitro,

Mango peel extract,

Natural putrescine, Rice

Kata Kunci:

Dihaploid, Ekstrak kulit

mangga, In vitro, Padi,

Putresin alami
Anther culture technique is frequently applied to obtain homozygous pure lines of double haploid (DH) in a short time, which is generally achieved through callus culture. Putrescine, one of polyamines growth regulator, has been used to promote embryogenesis in callus induction as well as regeneration. The aim of this study was to obtain regenerated plants using synthetic and natural putrescine in callus induction and regeneration media of anther culture for four rice genotypes (Oryza sativa L.). Anthers derived from selected $F_{3}$ genotypes with different genetic background namely Caka, SP, Sair and IRPW were used as explants. Results showed that callus was fruitfully induced from Caka in N6 medium with $10^{-3} \mathrm{M}$ synthetic putrescine, with $16.1 \%$ callus induction ability based on callus observation. Callus induced from genotype Caka had a crumb, compact structure and creamy white colour. MS medium was used for the regeneration with an addition of synthetic putrescine $10^{-3} \mathrm{M}$, however the regeneration did not succeed. An addition of synthetic putrescine was better than crude extract of putrescine in inducing callus, and callus successfully induced from genotype Caka. This will open the possibility to obtain double haploid rice plants.

Teknik kultur antera sering digunakan untuk memperoleh galur-galur murni double haploid (DH) yang homozigot dalam waktu singkat, yang umumnya dicapai melalui proses induksi kalus. Putresin sebagai salah satu zat pengatur tumbuh dari poliamin diketahui sangat penting bagi perkembangan embriogenesis kalus. Tujuan dari penelitian ini adalah memperoleh plantlet dari penggunaan putresin sintetik dan alami pada media induksi dan regenerasi kalus kultur antera secara in vitro terhadap empat genotip-genotip F3 padi hasil persilangan (Oryza sativa L.). Eksplan yang digunakan adalah antera padi generasi $\mathrm{F}_{3}$ terseleksi hasil persilangan Caka, SP, Sair dan IRPW. Hasil penelitian menunjukan bahwa induksi kalus berhasil terbentuk hanya dari genotip Caka pada media N6 dengan penambahan putresin sintetik $10^{-3}$ $M$, persentase pembentukan kalus sebesar $16,1 \%$. Kalus yang terbentuk dari genotip Caka memiliki struktur remah, kompak dan berwarna putih krem. Regenerasi menggunakan media dasar MS dengan penambahan putresin sintetik konsentrasi $10^{-3} \mathrm{M}$ belum berhasil. Penambahan putresin sintetik lebih efektif dalam pembentukan kalus dibandingkan putresin ekstrak alami. 


\section{PENDAHULUAN}

Padi (Oryza sativa L.) merupakan salah satu komoditi pangan terpenting di benua Asia terutama di Indonesia. Pertumbuhan penduduk di Indonesia diasumsikan masih 1,5\% per tahun, pada tahun 2050 mencapai 436 juta jiwa dan permintaan beras diperkirakan pada tahun 2050 meningkat menjadi sebesar 48,182 juta ton atau meningkat 45\% (Sudaryanto dkk., 2010). Kebutuhan padi yang terus meningkat membutuhkan teknologi unggul untuk menghasilkan pangan berkualitas. Perakitan varietas baru membutuhkan waktu yang relatif lama, melalui teknik haploid yaitu teknik kultur antera dan mikrospora secara in vitro dapat digunakan untuk mempercepat proses pembentukan populasi homozigot pada tanaman padi (Dewi dkk., 2006). Teknik kultur antera di Indonesia banyak dilakukan oleh para peneliti padi dalam perakitan tanaman padi di antaranya untuk mendapatkan galur-galur toleran naungan (Sasmita dkk., 2006), galur-galur toleran aluminium (Dewi dkk., 2009), perakitan tetua padi hibrida (Lestari \& Nugraha, 2006), perakitan padi tipe baru melalui seleksi silang berulang dan kultur antera (Abdullah dkk., 2008), dan pembentukan padi gogo dengan sifat-sifat tipe baru (Purbokurniawan dkk., 2014).

Fase perkembangan mikrospora yang dapat terdiferensiasi menjadi mikrospora embrionik atau kalus dan plantlet hijau adalah mikrospora berinti satu (uninucleat microspore) terutama pada fase tengah (mid uninucleat) (Suaib \& Arma, 2012). Keberhasilan kultur antera masih dibatasi oleh beberapa faktor, yaitu genotipe tanaman, komposisi media, pra perlakuan antera sebelum dikulturkan, fase pembentukan mikrospora pada saat antera dikulturkan, kondisi lingkungan tanaman yang akan diambil anteranya dan fase pengambilan malai (Kaushal et al., 2014). Bagheri \& Jelodar (2008), menunjukkan bahwa faktor genetik sangat mempengaruhi proses kultur antera, baik dalam induksi kalus maupun regenerasi. Lebih lanjut dilaporakn pula oleh Ezhova (2003) bahwa totipotensi sel bergantung pada aktivitas gen yang menentukan dan mempertahankan aktivitas meristematik sel, tingkat kandungan hormon, kepekaan terhadap hormon, serta aktivitas gen lain yang mengendalikan morfogenesis tanaman.

Berdasarkan faktor genetik terkait respon genotip terhadap perlakuan in vitro, secara berturutturut dari yang paling respon sampai ke kurang respon adalah sebagai berikut padi subspesies
Japonica, hasil persilangan Japonica $x$ Japonica, hasil persilangan Japonica $x$ Indica, hasil persilangan Indica $x$ Indica, dan Indica (Zapata et al., 1983). Rendahnya respon subspesies indica yang dikulturkan secara in vitro disebabkan karena ketidakmampuan atau rendahnya kemampuan mikrospora dalam menginduksi kalus. Peningkatan induksi kalus dan regenerasi tanaman hijau dapat diatasi antara lain dengan penggunaan poliamin pada komposisi media (Dewi dkk., 2004). Poliamin merupakan salah satu zat pengatur tumbuh penting yang mendukung pembelahan sel, jenisnya yang banyak dijumpai adalah putresin, spermidin, dan spermin (Davies, 1995). Salah satu buah-buahan yang mengandung poliamin adalah pada buah mangga (Malik \& Singh, 2004).

Dewi dkk. (2004) melaporkan bahwa putresin $10^{-3} \mathrm{M}$ lebih efisien dibandingkan dengan spermidin dan spermin dalam meningkatkan induksi kalus dan regenerasi tanaman pada kultur antera padi Taipei309 (japonica). Peranan putresin dan genotipe menjadi sangat penting dalam proses peningkatan induksi kalus dan mempengaruhi daya regenerasi kalus dalam teknik kultur antera. Penggunaan putresin alami sebagai salah satu pemanfaatan bahan alam pada media kultur antera in vitro padi sangat perlu diteliti dan dikembangkan lebih lanjut. Sampai saat ini laporan penggunaan putresin alami dari ekstrak kulit buah mangga untuk induksi dan regenerasi kalus hasil kultur antera belum banyak dikaji, sehingga riset ini penting untuk dilakukan.

\section{BAHAN DAN METODE}

Kultur antera padi dalam penelitian ini menggunakan empat genotipe padi hasil persilangan generasi $\mathrm{F}_{3}$ yaitu Caka (Ciapus $\mathrm{x}$ Kitaake/indica $\mathrm{X}$ japonica), SP (Sintanur $\mathrm{x}$ Pandanwangi/indica $x$ japonica), Sair (Salumpikit x IRAT/indica $x$ indica) dan IRPW (IR64 x Pandanwangi/indica $x$ japonica) yang terseleksi dari hasil riset sebelumnya. Genotip yang ditanam adalah genotip yang terseleksi berdasarkan marka molekuler dan fenotipik untuk karakter umur genjah pada genotip Caka; aromatik, ketahanan terhadap wereng cokelat pada genotip SP; toleran kekeringan pada genotip Sair; dan aromatik pada genotip IRPW. Setiap seri persilangan ditanam sebanyak 12 biji, sehingga total tanaman sebanyak 48 tanaman. Genotip ini akan dikaji dengan penambahan putresin sintetik $10^{-3} \mathrm{M}$ dan ekstrak kulit mangga sebagai sumber putresin alami dengan konsentrasi $2 \%, 4 \%, 6 \%$, dan $8 \%$ pada media. 
Media yang digunakan untuk induksi kalus ialah media N6 dan media regenerasi ialah media MS (Murashige Skoog). Zat yang ditambahkan dalam media yaitu putresin sintetik $10^{-3} \mathrm{M}$ dan ekstrak kulit mangga sebagai sumber putresin alami yang diekstraksi dengan pelarut methanol dengan perbandingan 1:10 berdasarkan metode Harbone (1996). Pembuatan ekstrak kulit mangga (Mangifera indica L.) yang digunakan merupakan mangga muda menuju fase pemasakan/ripening dengan kulit masih berwarna hijau (Malik \& Singh, 2004). Kulit mangga yang telah disiapkan merupakan kulit mangga varietas Arumanis. Perlakuan pada percobaan ini menggunakan Rancangan Acak Lengkap (RAL) faktorial terdiri dari 4 genotip padi generasi $\mathrm{F}_{3}$ (Caka, SP, Sair dan IRPW) dan 5 konsentrasi putresin (putresin sintetik $10^{-3}$ dan putresin alami $2 \%, 4 \%, 6 \%$, $8 \%)$. Penambahan puterisin dengan konsentrasi yang sama dilakukan pada media N6 untuk induksi kalus dan media MS untuk regenerasi.

\section{Pra Perlakuan Malai}

Kriteria malai yang digunakan adalah pada fase bunting yaitu keadaan mid uninucleat stage (fase akhir uninucleat atau awal binucleat) (Raina, 1993). Malai dibersihkan dengan aquadest dan disterilkan dengan alkohol 70\% kemudian dibungkus dengan tisu basah dan dimasukkan ke plastik bening. Selanjutnya dilakukan pra perlakuan malai dengan cara disimpan pada suhu $6^{\circ} \mathrm{C}$ selama $8-10$ hari, dengan tujuan untuk pengkondisian pematangan polen dan polen tidak menempel pada dinding polen (Kaushal et al., 2014).

\section{Sterilisasi Eksplan}

Sterilisasi eksplan dilakukan di dalam Laminar Air Flow Cabinet (LAF). Malai yang terpilih kemudian disterilkan dengan mercury chloride $(\mathrm{HgCl} 2)$ 0,1\% $+2 \mathrm{ml}$ menggunakan shaker selama 5 menit, kemudian dibilas dengan menggunakan aquades tiga kali.

\section{Induksi Kalus}

Antera (kotak sari) padi yang berjumlah enam dikeluarkan menggunakan pinset dan conde kemudian dimasukkan ke cawan petri yang sudah berisi media induksi kalus setiap cawan petri diisi 12 anther. Selanjutnya antera yang sudah diisolasi disimpan pada ruang kultur 30 laboratorium dalam keadaan gelap pada suhu $20^{\circ}-$ $27^{\circ} \mathrm{C}$ dengan kelembaban 50\%-70\%. Pengamatan induksi kalus dilakukan selama 10 minggu sejak anther berada pada media inkubasi. Setelah munculnya spot hijau/ tunas dilakukan pemindahan kalus ke media regenerasi.

\section{Regenerasi Kalus}

Kalus yang dipilih untuk diregenerasikan merupakan kalus bersifat embriogenik, kemudian dipindahkan ke media regenerasi dalam botol untuk diferensiasi tunas. Kalus embriogenik yang dipindahkan memiliki ciri adanya spot hijau/tunas setelah 10 minggu pada media inkubasi. Botol yang telah ditanami kalus kemudian diletakkan di atas rak kultur dengan intensitas penyinaran sebesar 1000 lux dan lama penyinaran 16 jam dalam sehari. Kelembaban diatur sekitar 50\% $-70 \%$ dan suhu antara $20^{\circ} \mathrm{C}-27^{\circ} \mathrm{C}$. Pengamatan rata-rata temperatur dan kelembaban relatif ruang kultur dilakukan. Pengamatan dilakukan untuk variable adalah: persentase kultur membentuk kalus (\%), warna kalus, dan tekstur kalus. Teknik pengumpulan dan perhitungan data dilakukan dengan menggunakan aplikasi Microsoft Excel 2010.

\section{HASIL DAN PEMBAHASAN}

\section{Persentase Pembentukan Kalus}

Hasil penelitian menunjukkan bahwa antera yang ditanam pada media sebesar $16,1 \%$ dapat diinduksi membentuk kalus. Pembentukkan kalus pertama terjadi pada genotip Caka minggu ke 8 minggu setelah kultur (MSK) pada media N6 dengan penambahan putresin sintetik $10^{-3} \mathrm{M}$. Tabel 1 menunjukkan persentase terbanyakpembentukan kalus hanya dihasilkan pada genotip Caka sebanyak $29(16,1 \%)$ antera dari total 180 jumlah antera genotip Caka yang dikultur pada perlakuan media N6 ditambah $10^{-3} \mathrm{M}$ putresin sintetik. Berdasarkan empat genotipe sumber eksplan tersebut, genotipe Caka merupakan satu-satunya genotipe yang memberikan respon pembentukan kalus. Berbagai penelitian menunjukkan bahwa tanaman-tanaman dari populasi hasil persilangan dengan Kitaake (subspesies Japonica) lebih responsif terhadap induksi kalus dan regenerasi tanaman (Abdullah dkk., 2008). Hal ini menunjukkan bahwa komposisi gen yang dimiliki oleh subspecies Japonica lebih responsif atau memiliki culture ability yang lebih baik dibandingkan dengan Indica. Tiga genotip hasil persilangan lainya yang tidak terbentuk kalus merupakan genotip yang masuk dalam subspesies Indica. 
Berdasarkan pengamatan terhadap pembentukan kalus, putresin sintetik lebih efektif dibandingkan dengan ekstrak kasar kulit mangga sebagai sumber putresin alami. Ekstrak kasar kulit mangga yang digunakan sebagai sumber putresin alami masih dalam bentuk crude/kasar, sehingga banyak mengandung berbagai zat lain, seperti pektin, tanin, gelatin, flavonoid dan sebagainya (Zhang et al., 2018). Menurut Newton et al. (2004) flavonoid merupakan senyawa fenol yang terdiri dari atom 15 karbon yang umumnya tersebar di dunia tumbuhan. Kelompok flavoniod sebagai penghasil zat fenolik ini yang akan menyebabkan pencoklatan atau browning pada jaringan eksplan.

Tabel 1. Induksi kalus dari antera padi yang dikulturkan pada media dengan penambahan putresin sintetik dan alami (\%)

\begin{tabular}{cccccc}
\hline \multirow{2}{*}{ Genotipe } & \multicolumn{5}{c}{ Persentase kultur membentuk kalus pada berbagai konsentrasi putresin } \\
\cline { 2 - 6 } & $10^{-3} \mathrm{M}$ & $2 \%$ & $4 \%$ & $6 \%$ & $8 \%$ \\
\hline IRPW & 0 & 0 & 0 & 0 & 0 \\
SP & 0 & 0 & 0 & 0 & 0 \\
Sair & 0 & 0 & 0 & 0 & 0 \\
Caka & 16,1 & 0 & 0 & 0 & 0 \\
\hline
\end{tabular}

Keterangan: $\quad{ }^{1}$ Dihitung berdasarkan rumus: $\sum$ antera yang membentuk kalus/ $\sum$ total antera yang dikultur $\mathrm{x} 100 \%$. Perlakuan $10^{-3} \mathrm{M}$ : N6 ditambah putresin sintetik konsentrasi $10^{-3} \mathrm{M}$; sedangkan perlakuan konsentrasi $2 \%$, $4 \%$, $6 \%$, dan $8 \%$ adalah media N6 yang ditambahkan putresin alami/ekstrak kulit mangga sesuai persentase yang ditambahkan.

\section{Kalus yang terbentuk}

Indikator perkembangan suatu eksplan pada kutur in vitro dapat dilihat berdasarkan gambaran visual kalus untuk diketahui sel-sel-nya masih aktif membelah atau mati. Pada perlakuan induksi kalus, ekspalan yang berhasil terbentuk kalus pada genotip CAKA, sedangkan tiga genotip lainya tidak berhasil membentuk kalus. Warna kalus yang terbentuk dari genotipe Caka adalah warna putih krem. Menurut Bishnoi et al. (2000) kalus yang berwarna putih krem, menunjukkan bahwa kalus tersebut embriogenik. Kualitas kalus dapat ditentukan dari tekstur kalus. Struktur kalus dapat dibedakan atas kalus yang bertekstur kompak dan bertekstur remah. Kalus yang memiliki kualitas baik ditandai dengan struktur kalus yang remah karena akan mudah ketika akan dilakukan pemisahan sel-selnya menjadi sel tunggal (Peterson \& Smith, 1991).
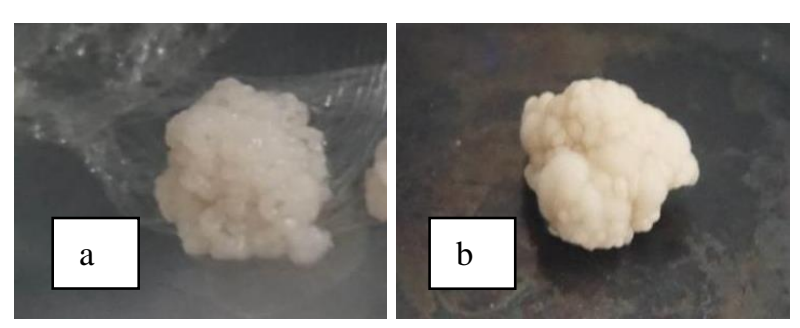

Gambar 1. Tekstur Kalus: a) Kalus bertekstur remah terbentuknya nodul- nodul ; b) Kalus bertekstur kompak
Gambar 1 menunjukkan visualisasi tekstur kalus. Dari pengamatan terlihat pada Gambar (1a.) kalus yang remah dicirikan dengan terbentuknya nodul-nodul sehingga mudah dipotong atau dipisah untuk disubkultur (diperbanyak), sedangkan kalus pada Gambar (1b.) teksturnya yang kompak dan terlihat padat.

Carsono \& Yoshida (2006a) menyatakan bahwa struktur kalus kompak merupakan kalus yang ikatan antar selnya kompak, terlihat padat, dan sulit dipisahkan. Adapun kalus remah secara visual merupakan kalus yang memilki ikatan renggang antar selnya dan kalus mudah dipisahkan. Shenoy et al. (2010), mengemukakan bahwa terbentuknya kalus yang berstruktur remah dipacu oleh adanya hormon auksin endogen yang diproduksi secara internal oleh eksplan yang telah tumbuh membentuk kalus tersebut.

\section{Regenerasi Tanaman}

Total kalus embriogenik yang diregenerasikan belum berhasil membentuk planlet. Sampai akhir pengamatan spot hijau pembentukan plantlet tidak terlihat sama sekali. Putresin sintetik dengan konsentrasi $10^{-3} \mathrm{M}$ sebagai zat pengatur tumbuh untuk diferensiasi sel membentuk tanaman yang ditambahkan pada media regenerasi MS, belum berhasil menginduksi kalus untuk membentuk plantlet.

Komposisi media dasar yang digunakan untuk perkembangan kalus tidak selalu optimal untuk regenerasi tanaman karena kebutuhan nutrisi dari 
dua fase perkembangan (proliferasi dan regenerasi kalus) bervariasi (Carsono \& Yoshida, 2006b). Penggunaan media MS pada penelitian ini bisa menjadi faktor belum berhasilnya upaya regenerasi yang dilakukan, keberhasilan regenerasi ini dipengaruhi beberpa faktor komposisi dan kepadatan media regenerasi yang digunakan, perimbangan zat pengatur tumbuh, intensitas dan lama penyinaran di ruang kultur atau growth chamber dan faktor lain yang belum diketahui.

\section{Temperatur dan Kelembaban pada Ruang Kultur}

Hasil pengamatan menunjukkan data suhu rata-rata $21,78^{\circ} \mathrm{C}$ selama 17 minggu pengamatan. Guiderdoni et al. (1992) menyebutkan bahwa tanaman tropis umumnya dikulturkan pada suhu yang sedikit lebih tinggi daripada tanaman empat musim, yaitu $27^{\circ} \mathrm{C}$ (kisaran suhu $24-30^{\circ} \mathrm{C}$ ). Rata-rata kelembaban harian selama 17 minggu pengamatan yaitu sebesar 53,54\%.

Nilai kelembaban pada pengamatan ini tidak memenuhi rata-rata anjuran kelembaban yang optimal. Kelembaban relatif optimum di dalam ruangan sekitar 70\% namun kebutuhan kelembaban di dalam wadah kultur mendekati $90 \%$ sehingga temperatur dan kelembaban secara abiotik mempengaruhi pertumbuhan induksi kalus. Kelembaban ruangan yang rendah menurut Wetherell (1982) akan menyebabkan penguapan air dari media kultur yang terlalu besar sedangkan kelembaban ruang kultur yang tinggi akan meningkatkan derajat kontaminasi.

\section{Mati Fisiologis Eksplan pada Media Kultur}

Matinya kultur secara fisiologis ini bisa disebabkan oleh beberapa faktor di antaranya terlalu lama kalus di dalam media tanam, sehingga mengalami degradasi fisiologis mengakibatkan fenomena browning. Fenomena browning dapat dibagi menjadi browning enzimatik dan pencoklatan non-enzimatik, dan browning enzimatik dikaitkan dengan oksidasi senyawa fenolik oleh polifenol oksidase (PPO) (Chuanjun et al., 2015).

Tabel 3. Presentase kultur mati fisiologis 10 MST (\%)

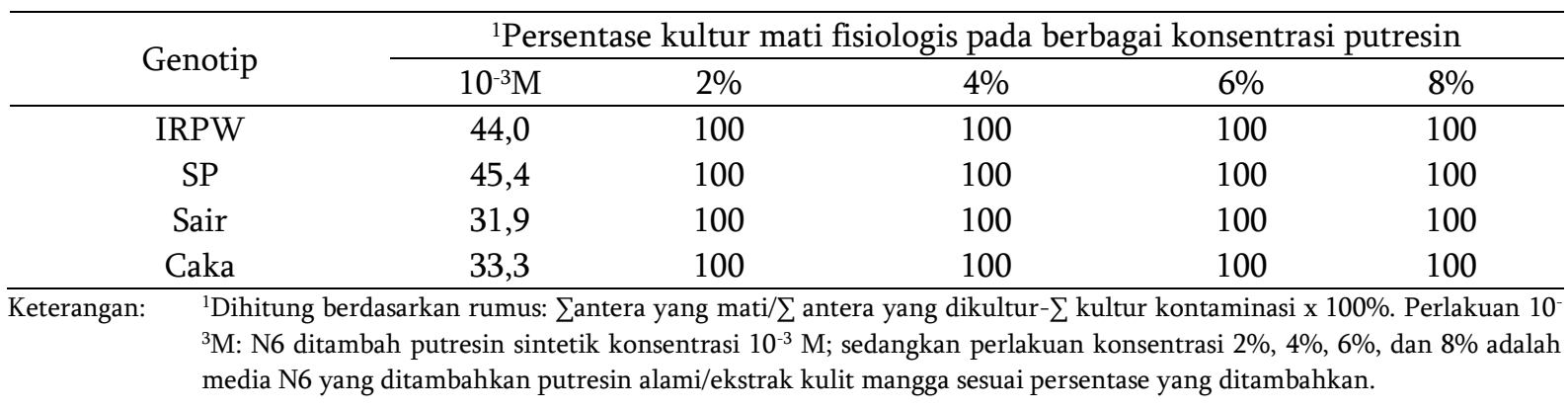

Pada Tabel 3 terjadi kematian fisiologis pada eksplan antera di seluruh perlakuan media N6 dengan penambahan putresin alami dari ekstrak kulit mangga pada seluruh konsentrasi. Hal ini diduga disebabkan adanya kandungan flavonoid. Flavonoid ini merupakan salah satu golongan fenol alam terbesar sehingga memicu aktivitas fenolik (PPO) pada jaringan tanaman yang berkontribusi terhadap pencoklatan enzimatik (Dong et al., 2016). Eksplan antera yang mengalami browning pada dasarnya dapat diklasifikasikan menjadi dua jenis yaitu browning secara langsung terjadi pada eksplan yang mengalami luka atau perubahan fisiologis dan browning bertahap dianggap sebagai ekspresi dari proses penuaan dari antera itu sendiri (Zhao et al., 2021). Upaya mengatasi permasalahan ini dapat dilakukan dengan menambahkan inhibitor enzim, antioksidan seperti asam askorbat dan tiosulfat, adsorben atau mempersingkat waktu subkultur untuk mengurangi terjadinya reaksi pencoklatan (Jones \& Saxena, 2013).

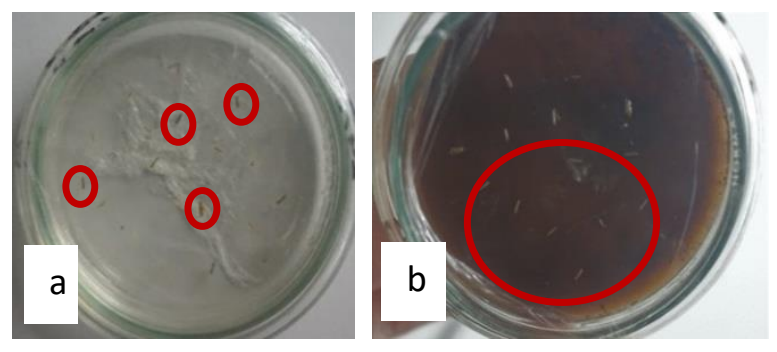

Gambar 5. Eksplan antera pada media induksi kalus unur 6 MSK. a) kultur eksplan mati fisiologis pada media N6+ putresin sintetik; b) kultur eksplan mati fisiologis pada media N6 + putresin alami; Kalus umur 6 MSK 


\section{KESIMPULAN}

Anter genotip Caka mampu menginduksi kalus dengan presentase sebesar 16,6\%, sementara genotip IRPW, SP, dan Sair belum mampu memebentuk kalus. Putresin sintetik lebih efektif digunakan untuk merangsang pembentukan kalus dibandingkan dengan ekstrak kulit mangga sebagai sumber putresin alami, karena kandungan flavonoid pada ekstrak kulit mangga yang masih kasar (crude) menyebabkan browning/mati fisiologis pada eksplan.Upaya regenerasi dari kalus yang terbentuk belum mampu membentuk plantlet. Ekstrak kulit mangga perlu diuji lanjut sebagai sumber putresin alami dan optimasi rekayasa media dasar yang tepat untuk keberhasilan regenerasi.

\section{UCAPAN TERIMA KASIH}

Penulis mengucapkan terimakasih kepada Dirjen Pendidikan Tinggi, Kemdikbudristek melalui Hibah Penelitian Strategis Nasional yang telah membantu dalam mendanai penelitian ini.

\section{DAFTAR PUSTAKA}

Abdullah, B, IS Dewi, Sularjo, H Safitri, dan AP Lestari. 2008. Perakitan padi tipe baru melalui seleksi silang berulang dan kultur antera. Pen. Pert. Tan. Pangan 27: 1-8.

Bagheri, N, and NB Jelodar. 2008. Combining ability and heritability of callus induction and green plant regeneration in rice antera culture. Biotech. 7: 287- 292.

Bishnoi, U, RK Jain, JS Rohilla, VK Chowdhury, KR Gupta, and JB Chowdhury. 2000. Antera culture of recalcitrant indica $\mathrm{x}$ Basmati rice hybrids. Antera culture of indicarice hybrids. Euphytica. 114: 93-101.

Carsono, N, and T Yoshida. 2006a. Identification of callus induction potential 15 Indonesian rice genotypes. Plant Prod. Sci. 9(1): 65-70.

Carsono, N, and T Yoshida. 2006b. Plant regeneration capacity of calluses derived from mature seed of five Indonesian rice genotypes. Plant Prod Sci. 9(1): 71-77.

Chuanjun, XU, RU Zhiwei, LI Ling, Z Biyu, H Junme, H. Wen, and $\mathrm{Hu} \mathrm{Ou}$. 2105. The effects of polyphenol oxidase and cycloheximide on the browning in Phalaenopsis explants. Hort Plant Journal. 1(3): 172-180.
Davies, PJ. 1995. Plant Hormones, Physiology Biochemistry and Molecular Biology. Kluwer Publishig. Dordrest.

Dewi, IS, BS Purwoko, H Aswidinnoor, dan IH Somantri. 2004. Kultur antera padi pada beberapa formulasi media yang mengandung poliamin. Jurnal Bioteknologi Pertanian. 9: 1419.

Dewi, IS, BS Purwoko, H Aswidinnoor, IH Somantri, dan MA Chozin. 2006. Regenerasi tanaman pada kultur antera beberapa aksesi padi indica toleran aluminium. Jurnal AgroBiogen. 2(1) : 30-35.

Dewi, IS, R Herawati, dan BS Purwoko. 2009. Keragaman genetik dan karakter agronomi galur haploid ganda padi gogo dengan sifatsifat tipe baru hasil kultur antera. Jurnal Agronomi Indonesia. 37(2) : 87 - 94.

Dong, YS, CH Fu, P Su, XP Xu, J Yuan, and S Wang. 2016. Mechanisms and effective control of physiological browning phenomena in plant cell cultures. Physiologia Plantarum. 156: 1328.

Ezhova, TA. 2003. Genetic control of totipotency of plant cells in an in vitro culture. Russian Journal of Development Biology. 34(4): 197204.

Harborne JB. 1996. Metode Fitokimia: penuntun cara modern menganalisis tumbuhan. Padmawinata K, Soediro I, penerjemah. Bandung : ITB Press. Terjemahan dari: Phytochemical Methods.

Jones, AM, and PK Saxena. 2013. Inhibition of phenylpropanoid biosynthesis in Artemisia annua L.: a novel approach to reduce oxidative browning in plant tissue culture. PLOS ONE. 8 (10): 1371.

Kaushal, L, R Sharma, SM Balachandran, K Ulaganathan, and V Shenoy. 2014. Effect of cold pretreatment on improving antera culture response of rice (Oryza sativa L.). Journal of Experiment in Biology and Agricultural Science. 2: 233-242.

Lestari, AP, dan Y Nugraha. 2006. Heterosis dan daya gabung galur mandul jantan dan pemulih kesuburan padi hasil teknik kultur antera. Jurnal Pertanian Penelitian Tanaman Pangan 25:157-162.

Malik, AU, and Z Singh. 2004. Endogenous free polyamines of mangos in relation to development and ripening. Journal of the 
American Society for Horticultural Science. 129:280 - 286.

Newton, RJ, W Tang, and LCV Outhavong. 2004. Exogenously added polyamines recover browning tissues into normal callus cultures and improve plant regeneration in pine. Physiologia Plantarum. 122(3):386-395.

Peterson, G, and R Smith. 1991. Effect of abscicic acid and callus size on regeneration of American and international rice varieties. Plant Cell Report. 10: 35-38.

Purbokurniawan, BS Purwoko, D Wirnas, dan IS Dewi. 2014. Potensi dan stabilitas hasil, serta adaptabilitas galur-galur padi gogo tipe baru hasil kultur antera. Jurnal Agronomi Indonesia 42:9-16.

Raina, SK. 1993. Plant regeneration by anther culture of javanica and javanica $\mathrm{x}$ indica rice lines. Indonesian Journal of Crop Science. 7 (1): 118.

Sasmita, P, BS Purwoko, S Sujiprihati, IH Somantri, IS Dewi, dan MA Chozin. 2006. Evaluasi pertumbuhan dan produksi padi gogo haploid ganda toleran naungan dalam sistem tumpangsari. Bulletin Agronomi. 34: 79-86.

Shenoy, V, L Kaushal, SM Balachandran, K Ulaganathan, AK Singh, and R Priyadarshi. 2015. Auxin to improve green plant regeneration of rice anther culture. International Journal of Agriculture and Crop Sciences 8: 15-26.
Guiderdoni, E, E Galinato, and G Vergara. 1992. Anthera culture of tropical japonica $\mathrm{x}$ indica hybrids of rice (Oryza sativa L.). Euphytica 62, 219-224.

Suaib, M, and J Arma. 2012. Pengembangan kultur mikrospora pada varietas padi ladang lokal asal Kendari. Jurnal Agronomi Indonesia. 40(2) : 99 -104 .

Sudaryanto, T, R Kustiari, \& HP Saliem. 2010. Perkiraan kebutuhan pangan dalam periode 2010-2050. Hlm 1-23. Dalam Analisis Sumber Daya Lahan Menuju Ketahanan Pangan Berkelanjutan. Badan Penelitian dan Pengembangan Pertanian, Jakarta.

Wetherell, DF. 1982. Pengantar Propagasi Tanaman Secara In Vitro. Semarang: IKIP Semarang Press.

Zhao, S, H Wang, K Liu, L Li, J Yang, X An, P Li, L Yun,and Z Zhang. 2021. The role of JrPPOs in the browning of walnut explants. BMC Plant Biology. $21(9)$ : $\quad 1 \quad-\quad 12$. https://doi.org/10.1186/s12870-020-02768-8

Zhang, Qing-Wen, Lin, Li-Gen \& Ye, Wen-Cai. 2018. Techniques for extraction and isolation of natural products: a comprehensive review. Chin Med 13 (20) : 1 - 26. https://doi.org/10.1186/s13020-018-0177-x

Zapata, FJ, MH Heu, \& GS Khush. 1983. Antera culture research for rice breeding at IRRI. Intern. Rice Res. Conf. IRRI, 19-23 April 1983, Los Banos- Philippines. 